\title{
RETENTION OF THE QUALITY OF BLACKCURRANT JUICE IN LACQUERED TINPLATE CANS
}

\author{
JaRL HägGman and TAINA KuUSI \\ The State Institute for Technical Research, Laboratory for Food Research and \\ Technology, Helsinki
}

Received April 18, 1963

In planning the marketing of blackcurrant juice, a material which has been studied in our laboratory for years (cf. 7, 8, 9), it is important to find a favourable solution to the problems arising with respect to storage and transport containers. The materials most commonly used today for this purpose, glass and plastic, have certain disadvantages, viz. the fragility and weight of glass, and the aroma loss which often occurs in plastic containers. Particularly in cases of long-distance transport, such as in exportation, the question of the most suitable packaging of the juice still presents a problem. Experience of the tinplate can is very limited in this respect. Its mechanical properties are well suited for the purpose, but its chemical suitability is less certain. Tinplate, which is tinned steel plate, is corroded by acid products, especially in the presence of free oxygen, and this may have results which are fatal both to the quality of the product and to the can. Corrosion may be prevented by using cans coated inside with acid-fast lacquers, but in practice the product does, nevertheless, generally come into direct contact with the metal at the sites of scratches and pores in the lacquer film. In addition to acids, blackcurrant juice contains also an ample measure of colouring matters of the anthocyan type; these combine with tin ions, dissolved by the acids from the plate, forming unpleasant looking insoluble compounds. Iron dissolved in the content of the can may also induce colour changes in the anthocyans. The practical purpose of the present study is to settle the question of whether lacquered tinplate cans are suitable for the storage of blackcurrant juice, and to determine the importance of the effect of scratches in the lacquer film on the quality of the juice.

\section{Material and methods}

The cans used in the experiments were nbeer cans" with dimensions of 66 $\varnothing \times 120 \mathrm{~mm}$. These were chosen because of their perfect lacquering. In the manu- 
facture of beer cans, the lacquering of the ends (3 coats) and the first lacquering operation of the can bodies are carried out on sheets in roller coating machines, while the second coat on the bodies is applied by spraying and subsequent stoving of the laqcuer on preformed bodies. During the production process, this type of can is subject to very strict inspection to ensure an extremely low level of metal exposure. The lacquering system used is flavour-free and also exceedingly acidfast; accordingly the requirements as regards corrosion resistance of the plate itself are rather low. In consequence, the tin layer is the thinnest used in commercial tinplate qualities; at the ends there is a steel quality (MC) which is in general considered unsuitable when canning corrosive products. Thus these cans do not correspond to ordinary cans, in which the metal exposure is greater because of scratches and pores in the lacquer film. With this in mind, half of the cans used in the experiment were purposely scratched inside the body before filling in order to get a picture of the maintenance of the quality of blackcurrant juice under conditions more closely resembling normal practice.

The blackcurrant juice ${ }^{1}$ subjected to experiment was prepared from frozen fruit, which was thawed by vapour treatment; the material consequently incorporated approximately 8 per cent more water. The juice was obtained by cold pressing, treated with pectinase, and filtered with pressure. No sugar or preservatives were added. The cans were filled with juice at $80^{\circ} \mathrm{C}$, and were immediately closed without steaming. For control, juice of the same batch was bottled in colourless glass bottles at the same temperature; the bottles were closed with screw caps of tinplate. In the cans and bottles the headspace was left as small as possible. After closing, the cans and bottles were pasteurized at $80^{\circ} \mathrm{C}$ for 30 minutes.

The storage temperature was $+4^{\circ} \mathrm{C}$ (for the bottles and some of the cans) and $+18^{\circ} \mathrm{C}$ (remainder of the cans). The bottles were stored in darkness. Unfortuately, the number of the original control bottles (control I) was not sufficient for the whole period of storage. However, a bottled juice of the same type, although not of the same batch (control II), was used during the last part of the storage (after 6-18 moths). Since the numerical values obtained in this series are not directly comparable with those of control I, the former values are not included in the tables. In any case, the use of control II has confirmed the absence of gross defects in the canned juices. Samples of the juices were investigated at the beginning and after storage for $3,6,9,12$, and 18 months.

In determining the quality of the juice, the following methods were used (compare earlier studies, 7, 8, 9). Vitamin $\mathrm{C}$ was assayed by the method of RoBINSON \& STOTz, with both formalin and peroxide correction taken into account (14); the method was slightly modified according to ERKAMA (4). The results are given as total ascorbic acid and corrected ascorbic acid, a correction being made in the latter value for both reductones (formalin correction) and reducing metals (peroxide correction) (6). The acid content and $\mathrm{pH}$ were determined electrometrically, using $\mathrm{pH} 8.2$ as end point (cf. 13). The acid content is expressed as

1) Blackcurrant juice was obtained from the canning factory of Länsi-Suomen Sokeritehdas Oy, and the cans from Oy G. W. Sohlberg Ab. 
$\mathrm{ml}$ of $0.1 \mathrm{n} \mathrm{NaOH} / 100 \mathrm{ml}$ of juice. The dry matter was usually determined refractometrically and given as a percentage. The strength of the colour was measured as absorption at the maximum (ordinarily at $520 \mathrm{~m} \mu$ ); in addition, the form of the absorption curve was ehecked to establish whether any changes had occurred in the hue $(5,8)$. The aroma number was measured in accordance with the BRUNNER \& SENN method (2); the values are given in $\mathrm{ml}$ of $0.1 \mathrm{n}$ bichromate/100 $\mathrm{ml}$ of juice. (On the reliability of this method see 9). For organoleptic appraisal, separate evaluations of colour, smell and taste were made, and also the sum of points was calculated (the maxima being 2, 4, 10 and 16 points, respectively). Colour and smell were judged from the undiluted samples, whereas for the taste test the juices were sweetened and diluted as follows: $30 \mathrm{ml}$ juice $+10 \mathrm{~g}$ sugar $\rightarrow 100 \mathrm{ml}$ of final dilution. The taste testing was performed by a trained panel consisting of $5-7$ persons. The results are given as uncorrected averages. The scheme of evaluation points was according to the original suggestion of Koch, as referred in BEYTHIEN's book (1, p. $356)$. Further to this, a general inspection of the juices and cans was made in order to establish whether any gross changes had taken place: precipitation of juice, change in colour, and corrosion of the can. The metal content of the juice was also investigated, in particular as regards the amounts of tin and iron, and in some cases also copper, which may influence the stability of ascorbic acid. Tin was assayed iodometrically after wet combustion by the method of Torleiv Taarland given in the proposal of the Scandinavian Method Committee for Foods (15), taking into account that the $\mathrm{CO}_{2}$ used was freed of oxygen by means of chromium sulphate- sulphuric acid (10, p. 425); this method is currently used in our laboratory.

Iron was assayed colorimetrically, after wet combustion, by the rhodanide (thiocyanate) method, and copper after wet combustion by the Na-diethyl-dithiocarbamate method recommended by the Scandinavian Method Committee for Foods (12).

\section{Results}

\section{Macroscopic examination of the juice and the cans}

The original juice was almost clear, only a very small amount of precipitate being noted on the bottoms of the containers. The changes which took place during storage were slight. Only after storage of 9 months was there a small amount of violet precipitate attached to the walls of scratched cans maintained at $18^{\circ} \mathrm{C}$. After 12 months the violet precipitate was established in both scratched and unscratched cans kept at $18^{\circ} \mathrm{C}$. After 18 months at $18^{\circ} \mathrm{C}$, more precipitate was noted on the bottom of the cans; this was flocculent and easily detachable. Precipitate was noted also on the walls of the cans, but here it was firmly attached and so thick that it was difficult to see the scratches beneath. The juice samples were taken in such a way that all the precipitate detached by shaking the can was included, but not the firmly attached violet precipitate on the walls.

Examination of the cans showed no signs of corrosion in unscratched cans during the whole of the experiment. In scratched cans, the sites of scratches were progressively enlarged, although only to a minor extent. No internal pressure was 
noted in any of the cans. Corrosion was more marked in cans kept at $+18^{\circ} \mathrm{C}$ than in those at $+4^{\circ} \mathrm{C}$. The surface of the undamaged lacquering showed no signs of any effects of the juice on the lacquering itself.

\section{Acid content, $p H$ and dry matter}

These determinations were made for control purposes since it is probable that only small changes take place in these values. Thus changes found in other values may be compared with these static ones.

As regards the $\mathrm{pH}$, the original value, measured from a bottled sample, was 3.38. During the first 12 months, the values of the different samples varied but little, remaining between 3.10 and 3.45 . The values obtained simultaneously varied at most by $0.2 \mathrm{pH}$ units. After 18 months at $+18^{\circ} \mathrm{C}$, the $\mathrm{pH}$ had risen significantly, being 3.73 in the unscratched, and 3.63 in the scratched cans.

Acid content in $\mathrm{ml}$ of $0.1 \mathrm{n} \mathrm{NaOH} / 100 \mathrm{ml}$ juice:

Bottle at $+4^{\circ} \mathrm{C}$

$\begin{array}{ccccccc}0 & 3 & 6 & 9 & 12 & 18 & \text { months } \\ 340 & 340 & 345 & & & & \end{array}$

Can, unscratched

$\begin{array}{ccccccc}\text { at }+4^{\circ} \mathrm{C} & -"- & 344 & 340 & 338 & 338 & \\ \text { at }+18^{\circ} \mathrm{C} & -"- & 344 & 345 & 353 & 343 & 363 \\ \text { n, scratched } & & & & & & \\ \text { at }+4^{\circ} \mathrm{C} & -"- & 358 & 338 & 355 & 359 & \\ \text { at }+18^{\circ} \mathrm{C} & -"- & 367 & 355 & 358 & 363 & 372\end{array}$

Dry matter refractometrically, per cent:

$\begin{array}{llllll}0 & 3 & 6 & 9 & 12 & 18 \text { months }\end{array}$

\begin{tabular}{|c|c|c|c|c|c|c|}
\hline Bottle at $+4^{\circ} \mathrm{C}$ & $7.3^{1}$ & 7.8 & 8.0 & & & \\
\hline Can, unscratched at $+4^{\circ} \mathrm{C}$ & $-"-$ & 7.8 & 8.2 & 7.8 & 8.0 & \\
\hline$-n-18^{\circ} \mathrm{C}$ & $-n-$ & 8.0 & 7.6 & 8.0 & 7.6 & 8.1 \\
\hline Can, scratched at $+4^{\circ} \mathrm{C}$ & $-"-$ & 8.4 & 8.5 & 8.6 & 8.2 & \\
\hline$+18^{\circ} \mathrm{C}$ & $-n-$ & 8.2 & 8.2 & 8.6 & 8.2 & .1 \\
\hline
\end{tabular}

It may be stated that no clear changes were discoverable.in the values of acid content and dry matter during storage. The relatively minor variations in the values were probably ascribable to small random differences in the samples of the series. The only regular difference was that the acid content and the dry matter of the un-

1) The initial value was determined by direct drying at $100^{\circ} \mathrm{C}$ until constant weight. In general, the values obtained by direct drying and by refractometer measurement agree within \pm 2 per cent. 
scratched cans was slightly lower than in the scratched cans; in unscratched cans the mean acid content was 345 , in scratched ones 358 , the latter value being 103.8 per cent of the former. Similarly, in unscratched cans the mean dry matter was 7.9 per cent, and in scratched ones 8.3 per cent, the latter value being 105.1 per cent of the former. This difference was small but regular, and it may be useful to keep this in mind in interpretation of the other values obtained.

Vitamin C. a) Total ascorbic acid in $\mathrm{mg} / 100 \mathrm{ml}$ juice.

\begin{tabular}{|c|c|c|c|c|c|c|}
\hline & 0 & 3 & 6 & 9 & 12 & 18 months \\
\hline Bottle at $+4^{\circ} \mathrm{C}$ & 60 & 18 & 6 & & & \\
\hline \multirow{2}{*}{\multicolumn{7}{|c|}{$\begin{array}{l}\text { Can, unscratched } \\
\text { at }+4^{\circ} \mathrm{C}\end{array}$}} \\
\hline & $-"-$ & 45 & 47 & 50 & 51 & \\
\hline \multicolumn{7}{|l|}{ Can, unscratched } \\
\hline at $+18^{\circ} \mathrm{C}$ & $-"-$ & 47 & 43 & 45 & 41 & 44 \\
\hline \multicolumn{7}{|l|}{ Can, scratched } \\
\hline at $+4^{\circ} \mathrm{C}$ & $-n-$ & 55 & 50 & 52 & 59 & \\
\hline \multicolumn{7}{|l|}{ Can, scratched } \\
\hline at $+18^{\circ} \mathrm{C}$ & $-n-$ & 53 & 47 & 50 & 53 & 44 \\
\hline \multicolumn{7}{|c|}{ b) Corrected ascorbic acid in $\mathrm{mg} / 100 \mathrm{ml}$ juice: } \\
\hline & 0 & 3 & 6 & 9 & 12 & 18 months \\
\hline \multirow{3}{*}{\multicolumn{7}{|c|}{$\begin{array}{l}\text { Can, unscratched } \\
\text { at }+4^{\circ} \mathrm{C}\end{array}$}} \\
\hline & & & & & & \\
\hline & $-"-$ & 26 & 29 & 33 & 24 & \\
\hline \multicolumn{7}{|l|}{ Can, unscratched } \\
\hline at $+18^{\circ} \mathrm{C}$ & $-n-$ & 25 & 25 & 19 & 16 & 15 \\
\hline \multicolumn{7}{|l|}{ Can, scratched } \\
\hline at $+4^{\circ} \mathrm{C}$ & $-"-$ & 35 & 32 & 30 & 18 & \\
\hline \multicolumn{7}{|l|}{ Can, scratched } \\
\hline at $+18^{\circ} \mathrm{C}$ & $-n-$ & 34 & 28 & 27 & 18 & 17 \\
\hline
\end{tabular}

Figures 1 and 2 illustrate these results. It may be noted that in the bottles the amount of ascorbic acid had rapidly decreased, particularly the corrected ascorbic acid; in 6 months this had become negligible. In the cans, the loss of ascorbic acid was considerably slower. As a possible explanation for this difference it might be supposed that it was due to the lower degree of air-tightness of the bottles as compared with the cans. Similar results have been reported in literature (3). The total ascorbic acid in the cans remained nearly constant during the experiment. The differences between the cans were small; storage at $+4{ }^{\circ} \mathrm{C}$ was more favourable than at $+18^{\circ} \mathrm{C}$, and the values for unscratched cans were somewhat lower than those for the scratched ones; the last mentioned difference is probably explained by the existence of parallel differences in the acid content and the dry matter. 


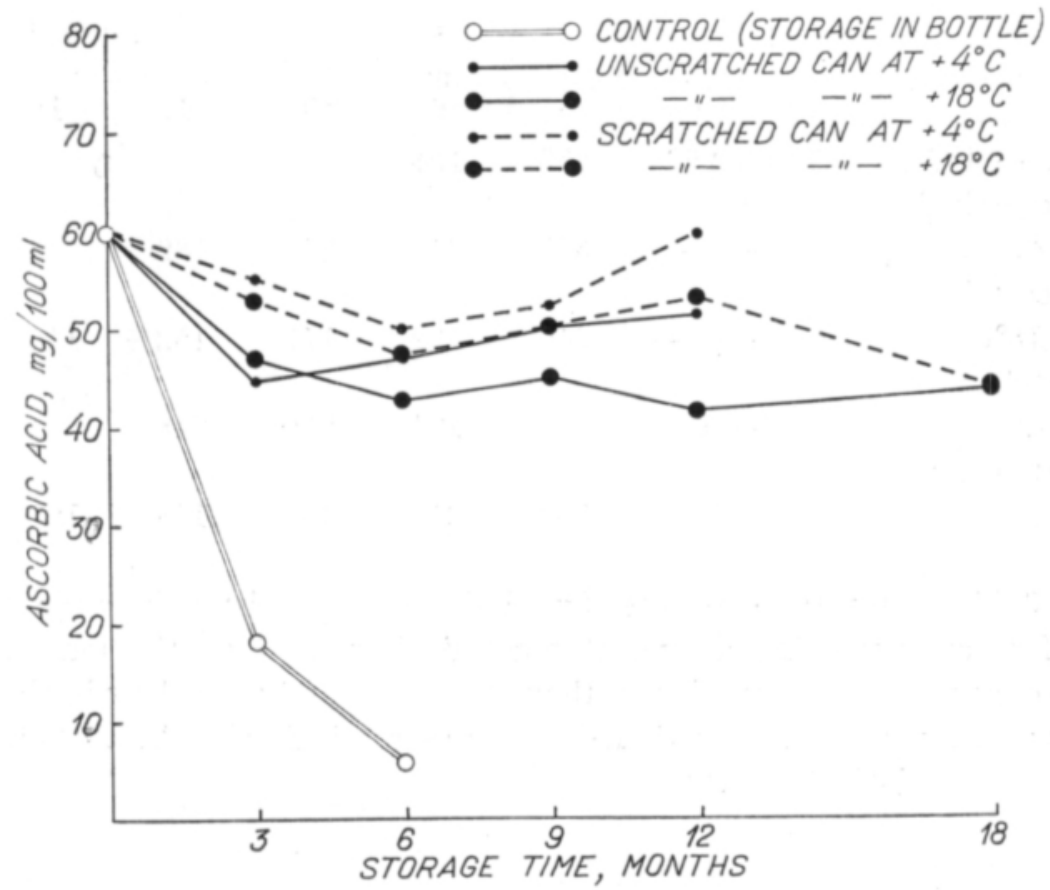

Fig. 1. Changes in the values of total ascorbic acid during storage of blackcurrant juice.

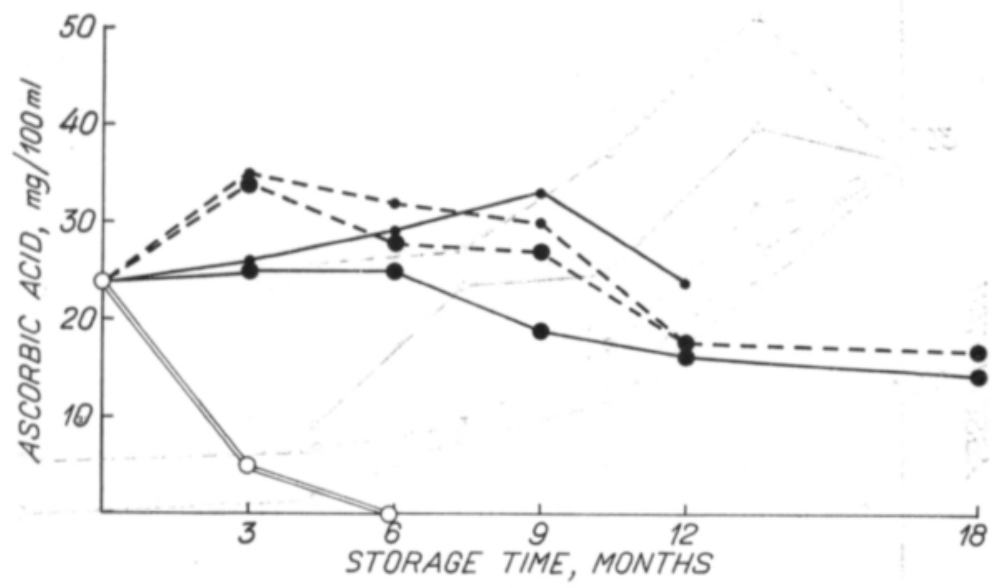

Fig. 2. Changes in the values of corrected ascorbic acid during storage of blackcurrant juice. Description of curves, vide Fig. 1 .

The corrected ascorbic acid decreased more clearly than the total ascorbic acid, but in any case the final values were higher than those for the bottle. Again in this series storage at $+4^{\circ} \mathrm{C}$ proved better than at $+18^{\circ} \mathrm{C}$, and the values for the scratched cans were somewhat higher than those for the unscratched ones. An exception was constituted by the unscratched cans kept at $+4^{\circ} \mathrm{C}$, in which in the last stages of storage the values were higher than elsewhere. 


\section{Colour}

Bottle at $+4^{\circ} \mathrm{C}$

$\begin{array}{cccccc}0 & 3 & 6 & 9 & 12 & 18 \text { months } \\ 292 & 255 & 194 & & & \\ -»- & 305 & 246 & 230 & 182 & \\ -»- & 240 & 192 & 177 & 152 & 146 \\ -»- & 350 & 294 & 256 & 248 & \\ -»- & 269 & 217 & 183 & 173 & 167\end{array}$

Fig. 3 illustrates these results. Small differences existed between the cans, these differences persisting during storage. With respect to the maintenance of colour, storage at $+4^{\circ} \mathrm{C}$ proved better than at $+18^{\circ} \mathrm{C}$, and the colour in the scratched cans was somewhat deeper than in the unscratched ones. As a whole changes in colour were relatively slight.

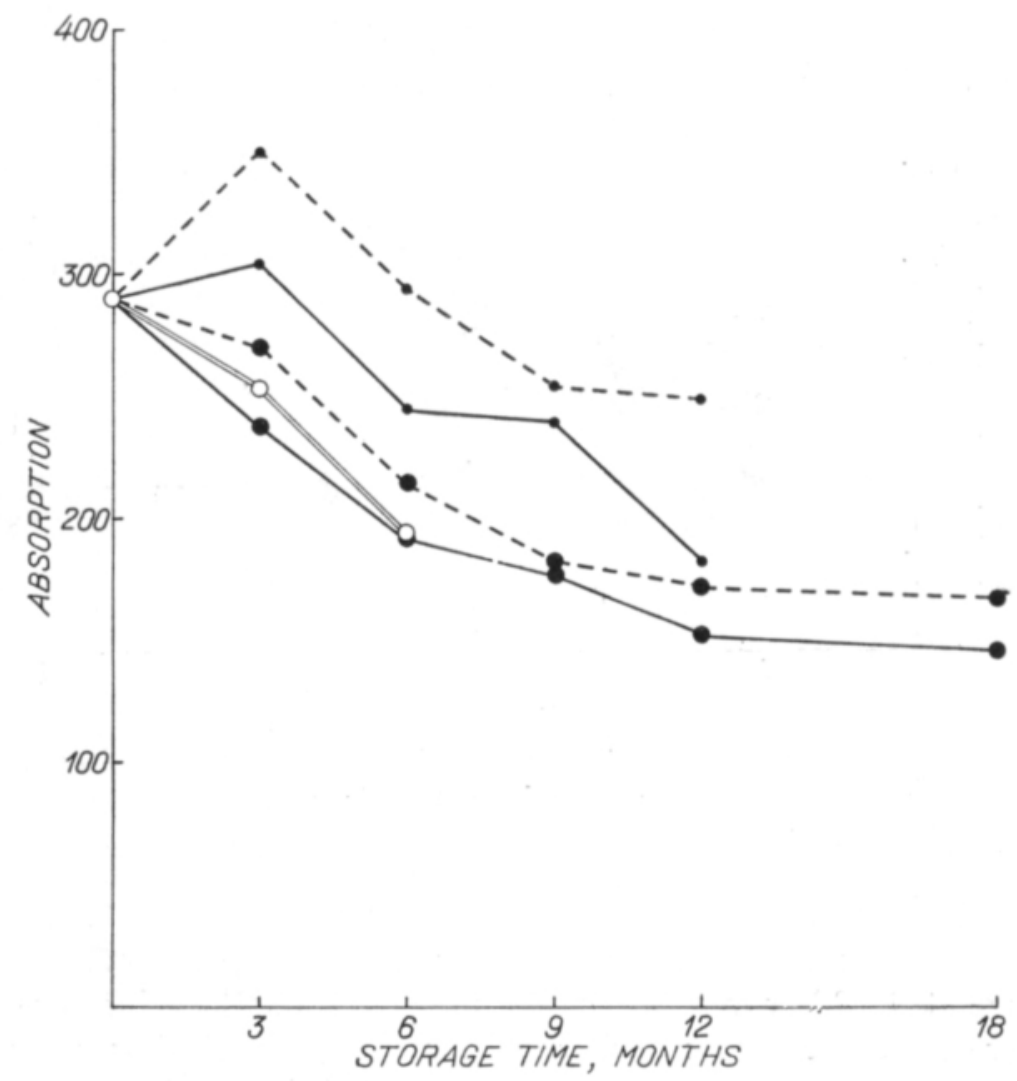

Fig. 3. Changes in colour strength during storage of blackcurrant juice. Dilution of the juices 1: 50 . Description of curves, vide Fig. 1. 
As regards the hue, possible faults in this may be identified from the wavelength of the absorption maximum: if tin is dissolved from the can, the maximum is shifted towards the red end of the scale (in a control experiment, where tin was added to juice, using $23.74 \mathrm{mg} \mathrm{Sn} / 100 \mathrm{ml}$ of the juice, the maximum was at $540 \mathrm{~m} \mu$, and the juice showed a typical blue-violet discoloration). On the basis of the absorption curves, it may be stated that only after storage for 18 months at $18^{\circ} \mathrm{C}$ was there observable a slight shift of the maximum. Thus the juices showed no clear-cut discoloration during the experiment.

\section{Organoleptic evaluation}

It is true that the results of this method of checking are not so exact as those of the other methods used, but when the quality of the juices has to be evaluated, this method is indispensable.

\section{Colour}

$\begin{array}{lccccc} & 3 & 6 & 9 & 12 & 18 \text { months } \\ \text { Bottle at }+4^{\circ} \mathrm{C} & 1.94 & 1.82 & & & \\ \text { Can, unscratched at }+4^{\circ} \mathrm{C} & 1.94 & 1.75 & 1.90 & 1.83 & \\ \text { Can, unscratched at }+18^{\circ} \mathrm{C} & 1.88 & 1.86 & 1.65 & 1.25 & 1.29 \\ \text { Can, scratched at }+4^{\circ} \mathrm{C} & 1.94 & 1.82 & 2.00 & 1.96 & \\ \text { Can, scratched at }+18^{\circ} \mathrm{C} & 1.94 & 1.86 & 1.35 & 1.38 & 1.42\end{array}$

The results show that the colour, visually evaluated, had weakened somewhat during storage. In this respect, juice stored in cans is equal to or better than that kept in bottles. On comparison of the cans, it may be observed that the effect of storage temperature becomes clear after 9 months: retention of the colour is better at $+4^{\circ} \mathrm{C}$ than at $+18^{\circ} \mathrm{C}$. In scratched cans, the colour is evaluated somewhat better than in unscratched ones. This may be connected with the acid content and dry matter being somewhat higher in the former case than in the latter.

\section{Smell}

Bottle at $+4^{\circ} \mathrm{C}$

Can, unscratched at $+4^{\circ} \mathrm{C}$

Can, unscratched at $+18^{\circ} \mathrm{C}$

Can, scratched at $+4^{\circ} \mathrm{C}$

Can, scratched at $+18^{\circ} \mathrm{C}$
$3 \quad 6$

$\begin{array}{ll}2.75 & 1.79\end{array}$

$3.38 \quad 2.21$

$3.38 \quad 3.00$

$3.13 \quad 2.36$

$3.31 \quad 3.00$
9

12

18 months

$\begin{array}{ll}1.70 & 2.67\end{array}$

$2.00 \quad 1.50$

2.60

3.04

$2.10 \quad 2.42$

2.33

In evaluation of the smell, the possibilities of error are rather great, and accordingly comparison of the results of judgments made at different times may perhaps be unreliable. However, the values obtained from the bottle were clearly lower than those from the cans. Divergences between the different cans were small; 
after 12 months storage a difference was apparent between storage at $+4^{\circ} \mathrm{C}$ and $+18^{\circ} \mathrm{C}$ in favour of the former, whereas before that time the differences had been less clear-cut. Scratching of the cans had no definite effect.

Taste

Bottle at $+4^{\circ} \mathrm{C}$

$\begin{array}{lllll}3 & 6 & 9 & 12 & 18 \text { months }\end{array}$

Can, unscratched at $+4^{\circ} \mathrm{C}$

$7.63 \quad 3.54$

Can, unscratched at $+18^{\circ} \mathrm{C}$

$8.12 \quad 5.75$

4.80

5.50

Can, scratched at $+4^{\circ} \mathrm{C}$

7.88

7.18

4.80

3.67

8.19

6.57

6.05

5.92

Can, scratched at $+18^{\circ} \mathrm{C}$

8.25

5.86

4.20

5.92

5.00

6.17

The values obtained with respect to the bottles were lower than those of the cans judged at the same time. In a comparison of the different cans, it can be seen that the differences are small and inconsistent, and neither temperature nor scratching shows any clear effects. In all the samples, during the course of storage, the taste showed a loss in quality; the juices were nevertheless still considered acceptable after 12 and 18 months. The results are illustrated in Fig. 4.

Combined organoleptic evaluation points

\begin{tabular}{lccrrl} 
& \multicolumn{1}{c}{6} & \multicolumn{1}{c}{6} & \multicolumn{1}{c}{12} & 12 & 18 months \\
Bottle at $+4^{\circ} \mathrm{C}$ & 12.32 & 7.15 & & & \\
Can, unscratched at $+4^{\circ} \mathrm{C}$ & 13.44 & 9.71 & 8.40 & 10.00 & \\
Can, unscratched at $+18^{\circ} \mathrm{C}$ & 13.14 & 12.04 & 8.45 & 6.42 & 8.29 \\
Can, scratched at $+4^{\circ} \mathrm{C}$ & 13.26 & 10.75 & 10.65 & 10.92 & \\
Can, scratched at $+18^{\circ} \mathrm{C}$ & 13.50 & 10.72 & 7.65 & 9.72 & 9.92
\end{tabular}

Here again it may be seen that the values for the bottles were lower than those for the cans. Moreover it is evident that there was a general lowering of the values in all series. Comparison of the cans shows that the advantage of a lower temperature was definite at the end of storage. In contrast, scratching evinced no clear effect. The results are illustrated in Fig. 4.

\section{Aroma number}

Bottle at $+4^{\circ} \mathrm{C}$

Can, unscratched at $+4^{\circ} \mathrm{C}$

Can, unscratched at $+18^{\circ} \mathrm{C}$

Can, scratched at $+4^{\circ} \mathrm{C}$

Can, scratched at $+18^{\circ} \mathrm{C}$

$\begin{array}{lllll}3 & 6 & 9 & 12 & 18 \text { months } \\ 74 & 59 & & & \\ 68 & 76 & 80 & 86 & \\ 67 & 74 & 74 & 88 & 86 \\ 72 & 86 & 78 & 95 & \\ 78 & 81 & 80 & 96 & 95\end{array}$

It is established that the aroma number had decreased in the bottles; conversely, it had somewhat increased in the cans. The differences between the cans were small. 

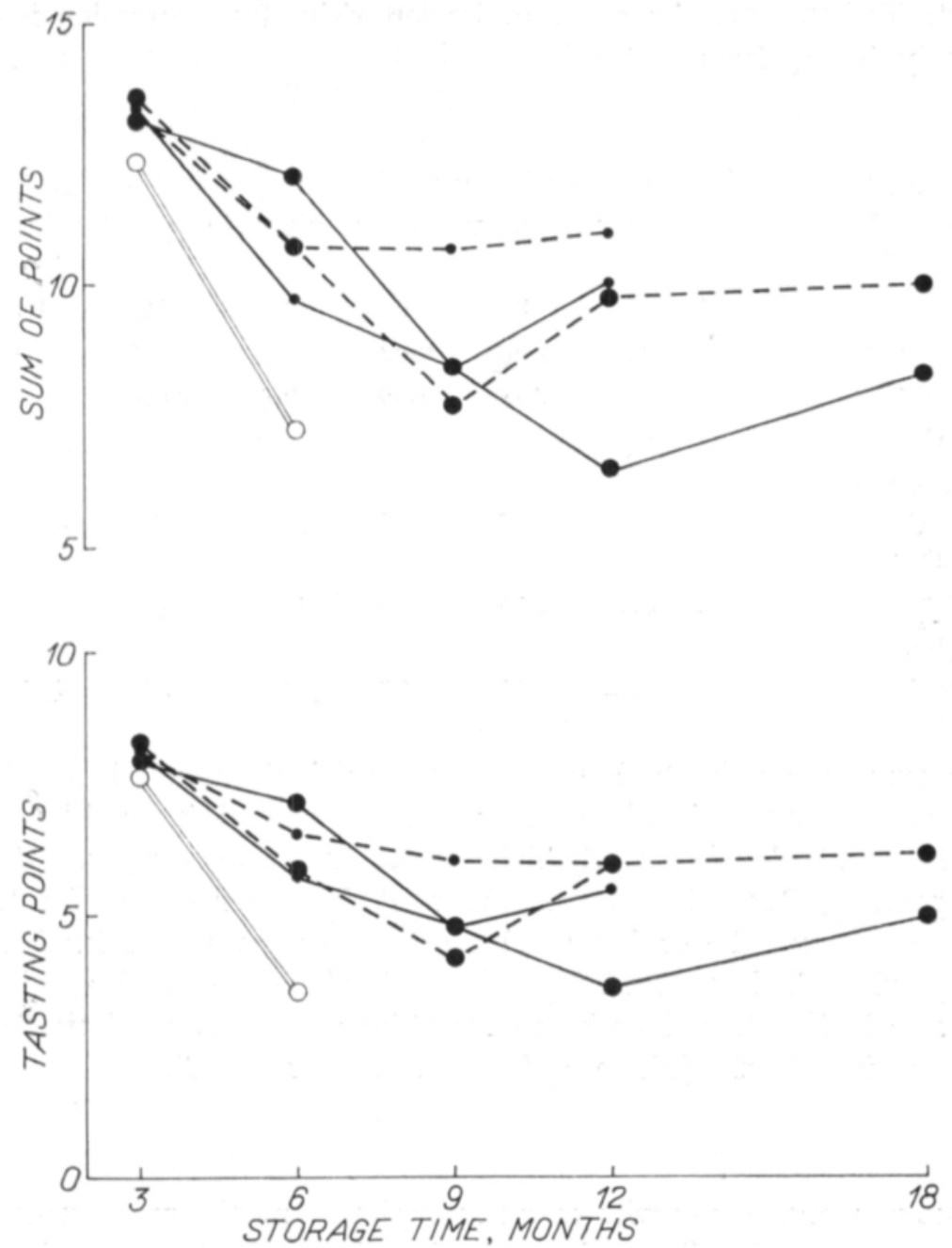

Fig. 4. Organoleptic evalution of blackcurrant juices after various storage times. Description of curves, vide Fig. 1.

\section{Metals}

Copper

Assays were made only in respect of the series of scratched cans kept at $+18^{\circ} \mathrm{C}$ (except the starting value, obtained from juice in bottle). The values are given in $\mu \mathrm{g} \mathrm{Cu} / 100 \mathrm{ml}$ of juice.

$\begin{array}{ccllll}0 & 3 & 6 & 9 & 12 & 18 \text { months } \\ 105.6 & 286.4 & 80.0 & 75.2 & 71.2 & 54.4\end{array}$

It can be seen that the amount of copper was very low, and that, as was to be excepted, the change during storage was a decrease rather than an increase. 
According to McConnell, the range of danger arising from corrosion is generally approximately $400 \mu \mathrm{g} / 100 \mathrm{ml}$.

\section{Iron}

The assays were carried out in such a: way that the precipitate firmly attached to the walls of the cans was omitted. The values are given in $\mu \mathrm{g} / 100 \mathrm{ml}$ of juice.

\begin{tabular}{|c|c|c|c|c|c|c|}
\hline & 0 & 3 & 6 & 9 & 12 & 18 \\
\hline Bottle at $+4^{\circ} \mathrm{C}$ & 554 & 530 & 564 & & & \\
\hline $\begin{array}{c}\text { Can, unscratched } \\
\text { at }+4^{\circ} \mathrm{C}\end{array}$ & $-n-$ & 488 & 592 & 664 & 480 & \\
\hline $\begin{array}{c}\text { Can, unscratched } \\
\text { at }+18^{\circ} \mathrm{C}\end{array}$ & $-»-$ & 488 & 528 & 598 & 580 & 494 \\
\hline $\begin{array}{c}\text { Can, scratched } \\
\text { at }+4^{\circ} \mathrm{C}\end{array}$ & $-"-$ & 488 & 516 & 858 & 530 & \\
\hline $\begin{array}{c}\text { Can, scratched } \\
\text { at }+18^{\circ} \mathrm{C}\end{array}$ & $-n-$ & 632 & 572 & 1590 & 740 & 420 \\
\hline
\end{tabular}

The amount of iron in the bottles was the original amount in the juice with no effect from cans. When the different cans were compared, it could be established that the only sample showing clearly higher values than the control were the scratched cans kept at $+18^{\circ} \mathrm{C}$. It was also observed that after storage for 18 months the amounts of iron were lower than had been the case 6 months earlier. It is possible that the iron which had dissolved from the walls of the cans had remained in the precipitate attached to the walls, which was not included in the analysis. As a whole, the increase of iron in the juice was found to be very small.

Tin

Analyses were made only with canned samples, as no tin was excepted to have dissolved from the bottles. The values are given in $\mathrm{mg} \mathrm{Sn} / 100 \mathrm{ml}$ of juice.

$\begin{array}{lccccc} & 3 & 6 & 9 & 12 & 18 \text { months } \\ \text { Can, unscratched at }+4^{\circ} \mathrm{C} & 1.332 & 0.653 & 0.254 & 1.668 & \\ \text { Can, unscratched at }+18^{\circ} \mathrm{C} & 1.623 & 0.810 & 0.356 & 1.837 & - \\ \text { Can, scratched at }+4^{\circ} \mathrm{C} & 0.638 & 0.236 & 0.661 & 0.991 & \\ \text { Can, scratched at }+18^{\circ} \mathrm{C} & 0.638 & 0.433 & 1.119 & 2.610 & 0.753\end{array}$

On considering these values, it is noted that on each occasion more tin had gone into solution at $+18^{\circ} \mathrm{C}$ than at $+4^{\circ} \mathrm{C}$. At first, the values were greater in the unscratched than in the scratched cans, but after 9 months of storage the highest values were those of the scratched cans kept at $+18^{\circ} \mathrm{C}$. The fact that after 18 months the values in this series had decreased was probably attributable to part of the tin remaining in the firmly attached precipitate on the walls of the cans and thus being omitted from the juice samples. 
As a general conclusion it may be stated that the cans used were well suited to the storage of blackcurrant juice. No serious corrosion occurred in the cans, not even in the scratched ones, and the amount of tin and iron which entered into solution from the cans was very low. In consequence, no remarks of metallic taste have been presented in the organoleptic evaluation. During storage a progressive loss in the quality of the juice was observed. This was noted in the organoleptic evaluation, the decrease of ascorbic acid, the loss of colour and a slight rise in the aroma number; the loss in quality was noted, however, for the juice kept in cans as well as that kept in bottles.

In particular it was found that the retention of ascorbic acid was better in cans than in the control samples. As regards the colour, where the harmful effect of the can might become apparent, these experiments demonstrated no clear-cut effects.

The longest storage period in this series was 18 months, at which time, when kept at $18^{\circ} \mathrm{C}$, the juices began to show precipitation. After 12 months, the changes which had occurred were rather slight. Thus, the practical conclusion is that blackcurrant juice could be kept in this type of can at most from one harvest to the following one, but preferably not longer. From the point of view of quality, a low storage temperature is to be recommended.

\section{REFERENCES}

(1) Beythien, A. \& Diemair, W. 1957. Laboratoriumsbuch für den Lebensmittelchemiker. 7. Aufl. Dresden \& Leipzig.

(2) Brunner, H. \& Senn, G. 1957. Die quantitative Kontrolle des Aromaentzuges aus Fruchtsäften in Aromarückgewinnungsanlagen. Schweiz. Ztschr. f. Obst- u. Weinbau 66, 25: 587-591.

(3) CuRDA, D. 1959. The oxidation-reduction potential in foods, especially in canning materials. Orig.: Sb. Vysoke Skoly Chem.-Technol. Praze. Oddil Fak. Potravinareske Technol. 3: 43-156, 1959. Ref. Chem. Abstr. 57, 5: 6377 e.

(4) ErкAмA, J. 1946. Kolorimetrisestä C-vitamiinin mäărityksestä 2,6-diklorfenoli-indofenolilla. Suomen Kemistilehti 19: 21-25.

(5) Kieser, M. E., Pollard, A., Trmberlake, C. F. \& Moseley, M. R. 1953. Factors affecting the quality and stability of concentrated fruit juices. 1. Black-currant and apple concentrates. Ann. Rep. Long Ashton, Res. Sta. p. 189-198.

(6) KuUsI, T. 1960. Reductone interference in the assay of ascorbic acid. A comparative study of different methods of analysis. Suomen Kemistilehti B 33: 139-143.

(7) $\quad-\quad$ 1961. On the factors affecting the stability of ascorbic acid in black-currant. Experiments on the enzymatic and non-enzymatic destruction of ascorbic acid. Valt. tekn. tutk. lait. tiedotus Sarja IV Kemia 34: 1-19.

(8) - 1961. The influence of the presence of cloud on the quality of black-currant juice, and particularly on the stability of ascorbic acid. Ibid. 39: 1-28.

(9) - 1962. Versuche über die Technologie der Produkte aus schwarzen Johannisbeeren und die Erhaltung von deren Aroma. Flüssiges Obst 29, 10: 14-17.

(10) Lingane, J. J. \& Pecsoc, R. L. 1948. Preparation of standard chromous sulfate or chromous chloride solutions of determinate concentration. Anal. Chem. 20, 5: 425-428. 
(11) McConnell, E. R. Factors contributing to internal corrosion of canned food containers. Rep. Continental Can Co, Inc., 12-7-60.

(12) Nordisk metodik-kommitte för livsmedel $\mathrm{Nr} 30$, UDC 546. 56, 1958.

(13) Official methods of analysis of the association of official agricultural chemists 9 ed. Washington 1960.

(14) Robinson, W. B. \& Stotz, E. 1945. The indophenol-xylene extraction method for ascorbic acid and modifications for interfering substances. J. Biol. Chem. 160: 217-225.

(15) Taarland, T. 1951. Bestemmelse av tinn i naeringsmidler. Nordisk metodik-kommitte för livsmedel, proposition.

S E L O T U S :

MUSTAHERUKKAMEHUN LAADUN SÄILYMINEN LAKATUISSA PELTIPURKEISSA
SÄILYTETTÄESSÄ

JARL Häggman ja TAINa KuUSI

Valtion teknillinen tutkimuslaitos, Elintarviketeollisuuslaboratorio, Helsinki

Kylmäpuristettua, sokeroimatonta mustaherukkamehua säilytettiin 18 kuukauden ajan lakatuissa ns. olutpurkeissa», joista puolessa lakkaus oli ehjä, puolessa naarmutettu. Kontrollina oli säilytys lasipulloissa. Mehuista analysoitiin määrätyin väliajoin kuiva-aine, $\mathrm{pH}$, happomäärä, C-vitamiini, värinvoimakkuus, aromiluku sekä kupari, rauta ja tina. Lisäksi mehujen laatu arvosteltiin organoleptisesti.

Tulokset osoittivat, että k.o. purkit soveltuivat hyvin mustaherukkamehun säilytykseen. Purkeissa ei todettu merkittävää korrosiota, ei edes naarmutetuissa purkeissa, ja liuenneen tinan ja raudan määrä oli hyvin pieni. Organoleptisessä arvostelussa ei myöskään huomautettu metallimaisesta mausta. Säilytyksen aikana mehun laatu huononi asteettain. Tämä ilmeni organoleptisessä arvostelussa sekä C-vitamiinin alenemisena, värin heikkenemisenă ja aromiluvun vähäisenä nousuna. Laadun huononeminen oli kuitenkin todettavissa sekä purkeissa että pulloissa säilytetyssä mehussa.

Erityisesti on mainittava, että askorbiinihapon säilyminen oli purkeissa jopa parempi kuin kontrollisarjasssa. Väriin nähden, jossa purkkien haittavaikutus erityisesti saattaa tulla esille, ei mainittavia virheellisyyksiä voitu todeta.

Purkeissa säilytettäessä todettiin $18 \mathrm{kk}$. kuluttua saostumista $+18^{\circ}$ säilytettäessä. Vielä 12 kk. säilytyksen jälkeen muutokset olivat jokseenkin vähäiset. Käytännössä mustaherukkamehua voitaisiin säilyttää k.o. purkeissa korkeintaan satokaudesta toiseen, mutta ei kauempaa. Laadun säilyttämisen kannalta alhainen lämpötila on suositeltava. 